\title{
A study of site characteristics affecting seismic strengthening strategy
}

\author{
G. C. Yao \& W. C. Chen \\ Department of Architecture, National Cheng Kung University, Taiwan
}

\begin{abstract}
This study demonstrates that geological characteristics will affect seismic retrofit strategy. An old temple had been retrofitted before but still suffered serious damage from recent earthquakes. In order to find a good solution to strengthen the temple, a computer structural model of the target building was built and its accuracy was verified by using ambient vibration experiment. From nearby seismic station records, we then studied the strong motion characteristics using response spectrum analysis. The results indicated that increasing the building's stiffness would also increase the input energy. Therefore, we proposed another retrofit scheme to consume earthquake energy instead of increasing the building's stiffness. A conceptual strengthening model was developed and computer analysis was targeted for the temple's inter-story drift ratio to be kept under $0.5 \%$. The effect of the final design was analyzed and discussed.
\end{abstract}

Keywords: retrofit, response spectrum analysis, inter-story drift ratio.

\section{Introduction}

Since the 1999 Chi-Chi Earthquake, higher requirements of seismic capacity have been increasingly recognized in Taiwan. However, many old buildings can only be retrofitted rather than rebuilt. There are plenty of retrofit methods. In addition to raising the stiffness of buildings to reduce the earthquake deformation [1-3], consuming the input energy of earthquakes can also be used for retrofitting purpose [4]. In general, traditional retrofit methods are about adding shear walls and wing walls. Besides, RC jacketing system and Steel-Framing System are also common in Taiwan. These seismic retrofit strategies are to raise the strength and stiffness of buildings to resist earthquakes, and this is considered 
inexpensive and effective. But occasionally these methods cannot achieve the expected results if site conditions have special ground movement characteristics.

A case is applied in this study to demonstrate the importance of geological characteristics since they will affect seismic retrofit strategies. An old temple located in central Taiwan had been retrofitted before but still suffered damages from recent earthquakes. Our team was commissioned to help propose a feasible retrofit method.

\section{Dynamic analysis}

The old temple has two buildings. The front building is seven stories high, and the back one has three stories. The first and second stories of the two buildings are connected together. We built a computer structural model of the temple (Figure 1) and verified its accuracy by using ambient vibration experiment.

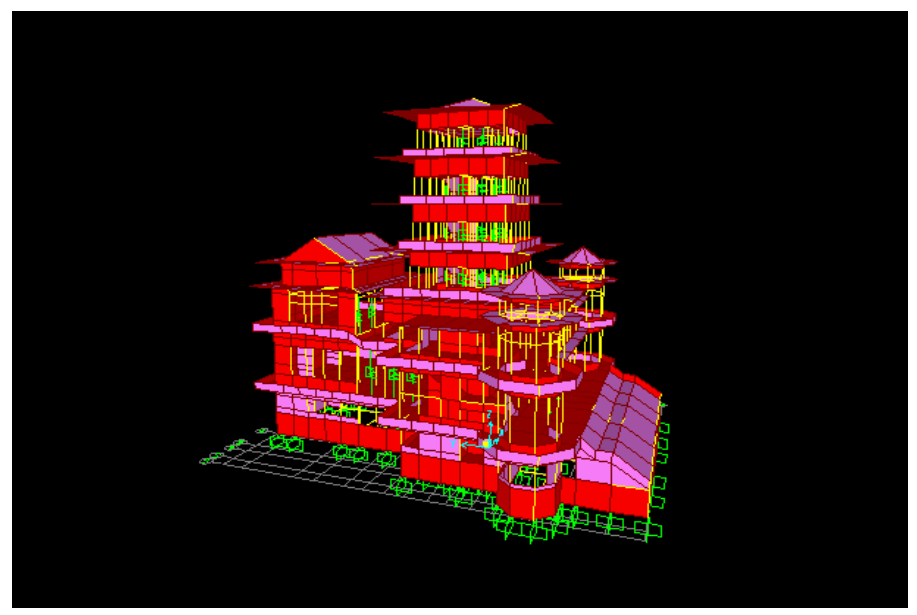

Figure 1: $\quad$ The computer structural model.

The ambient vibration experiment was conducted to measure the vibration of the target building for 300 seconds. The acceleration sensors were placed on the 1st floor and the 7 th floor respectively to measure the ground motion and the building's vibration. The vibration measured on the 1st floor was considered as the input signal while that on the 7 th floor was treated as the output signal. By using system identification, the frequency response function (FRF) could be obtained and thus the natural frequency of the temple was accurately found. Table 1 showed the natural frequency of the temple compared to the natural frequency of the computer structural model. The result indicated that the two were closely related, which represented that the computer structural model could actually simulate the structural behaviors of the target building. Meanwhile, the computer model could also provide the estimated analysis with reliable accuracy. 
Table 1: $\quad$ Natural frequency of the temple and the computer structural model.

\begin{tabular}{|c|c|c|c|c|c|c|c|}
\hline \multirow{3}{*}{$\begin{array}{l}\text { Ambient } \\
\text { vibration } \\
\text { experiment }\end{array}$} & \multirow{2}{*}{$\begin{array}{l}\text { Natural } \\
\text { frequency }\end{array}$} & \multicolumn{3}{|c|}{ East-west } & \multicolumn{3}{|c|}{ North-south } \\
\hline & & $1.61 \mathrm{~Hz}$ & $1.56 \mathrm{~Hz}$ & $1.60 \mathrm{~Hz}$ & $1.61 \mathrm{~Hz}$ & $1.58 \mathrm{~Hz}$ & $1.63 \mathrm{~Hz}$ \\
\hline & $\begin{array}{c}\text { Average } \\
\text { value }\end{array}$ & \multicolumn{3}{|c|}{$1.59 \mathrm{~Hz}$} & \multicolumn{3}{|c|}{$1.61 \mathrm{~Hz}$} \\
\hline $\begin{array}{c}\text { Computer } \\
\text { structural } \\
\text { model }\end{array}$ & $\begin{array}{l}\text { Natural } \\
\text { frequency }\end{array}$ & \multicolumn{3}{|c|}{$1.56 \mathrm{~Hz}$} & \multicolumn{3}{|c|}{$1.62 \mathrm{~Hz}$} \\
\hline
\end{tabular}

After the accuracy of the model was confirmed, real earthquake records were used for computer dynamic analysis. First, according to the seismic codes we calculated the design ground acceleration of the temple. Then we adjusted the peak ground acceleration (PGA) of the selected earthquake records to be exactly the same as the design ground acceleration. In comparison with all the other earthquake records, the 1999 Chi-Chi Earthquake was considered most representative and was chosen as the design earthquake. Comparing to the 2010 Jia-Shian Earthquake, the strongest ground motion happened in a very short moment (Figure 2) and the PGA was much stronger than the rest ground acceleration. On the contrary, the Chi-Chi Earthquake lasted longer, and not only one peak ground motion but several strong ones also happened in the record (Figure 3).

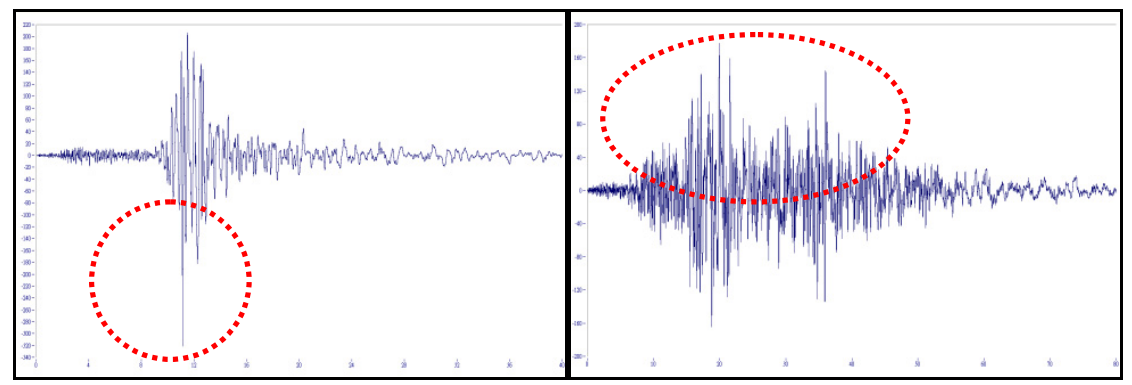

Figure 2: The Jia-Shian Earthquake Figure 3: The Chi-Chi Earthquake record. record.

From the dynamic analysis, we analyzed the temple's vibration behaviors during earthquakes. Then the deformation of each floor was calculated to obtain the inter-story drift ratio shown in Table 2 . According to the seismic codes, a new building's inter-story drift ratio must be kept under $0.5 \%$. But it was found that the 4th floor to the 7th floor of the front building and the 3rd floor of the back building swayed over this value. In the meantime, because the back 
building had lots of walls which increased the local stiffness, the center of stiffness was close to the back building. Therefore, the temple was seriously affected owing to torsional effect.

Table 2: $\quad$ The temple's inter-story drift ratio.

\begin{tabular}{|c|c|c|c|c|c|c|c|}
\hline \multicolumn{8}{|c|}{ The inter-story drift ratio of the front building in east-west direction } \\
\hline floor & $1 \mathrm{st}$ & 2nd & $3 \mathrm{rd}$ & 4 th & 5 th & 6 th & 7 th \\
\hline inter-story drift ratio (\%) & 0.08 & 0.37 & 0.24 & 0.57 & 0.67 & 0.65 & 0.60 \\
\hline \multicolumn{8}{|c|}{ The inter-story drift ratio of the front building in north-south direction } \\
\hline floor & $1 \mathrm{st}$ & 2 nd & $3 r d$ & 4th & 5 th & 6 th & 7 th \\
\hline inter-story drift ratio (\%) & 0.06 & 0.39 & 0.31 & 0.52 & 0.56 & 0.50 & 0.42 \\
\hline \multicolumn{8}{|c|}{ The inter-story drift ratio of the back building in east-west direction } \\
\hline floor & $1 \mathrm{st}$ & 2nd & $3 \mathrm{rd}$ & & & & \\
\hline inter-story drift ratio (\%) & 0.09 & 0.35 & 0.21 & & & & \\
\hline \multicolumn{8}{|c|}{ The inter-story drift ratio of the back building in north-south direction } \\
\hline floor & $1 \mathrm{st}$ & 2 nd & $3 \mathrm{rd}$ & & & & \\
\hline inter-story drift ratio (\%) & 0.05 & 0.24 & 0.85 & & & & \\
\hline
\end{tabular}

In this study, the temple's inter-story drift ratio was chosen to be the design criteria and we tried to keep this ratio under $0.5 \%$ to maintain the elastic behavior of the structure. Another reason to select the design criteria instead of reviewing the stress in the structural elements was mainly because we could not obtain complete information about the construction materials and the plans of reinforcing bars. Besides, the temple was damaged in previous earthquakes and was retrofitted afterwards without leaving complete records. Therefore the structure details were not available.

\section{Earthquake records analysis}

The dynamic analysis demonstrated the temple's vibration behaviors. However, we believed that the geological characteristics around the building were vital while making appropriate retrofit designs. Take Taipei area for example: Taipei is a basin and the geology is soft. This geological characteristic will magnify earthquake waves and make bigger ground motion. The building's vibration behaviors are mainly influenced by the ground motion during earthquake. Therefore, in order to realize the geological characteristics around the temple, we chose one seismic station nearest the temple (1.5 kilometers) set by Central Weather Bureau. The station recorded detailed data of each earthquake, and 
among all the records three strong earthquake records (921 Chi-Chi, 1022 and 0304 Jia-Shian Earthquakes) were selected to represent the ground movement characteristics of the area around the temple.

The earthquake records selected were calculated by the response spectrum analysis. In a response spectrum, $\mathrm{X}$-axis was the natural frequency of buildings, and the peak in the graph indicated the building frequency with the biggest energy during the earthquake.

Figures 4 and 5 were the response spectra of the three earthquake records in two different directions (east-west and north-south). The dotted lines in the two figures were the natural frequency of the temple. From the curves in the figures, we realized that if the natural frequency of the temple increased, it attracted more energy into the building. The results pointed to an important message; that is,

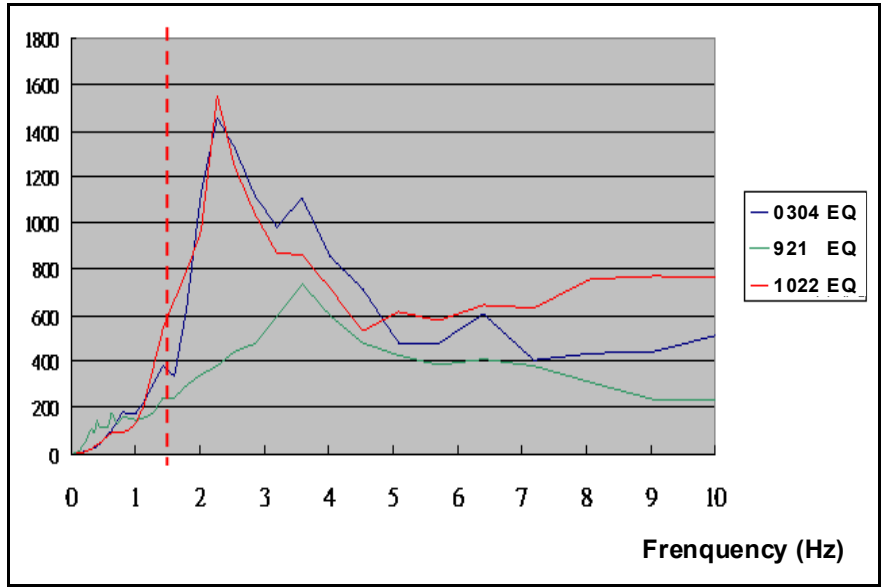

Figure 4: The response spectrum (east-west).

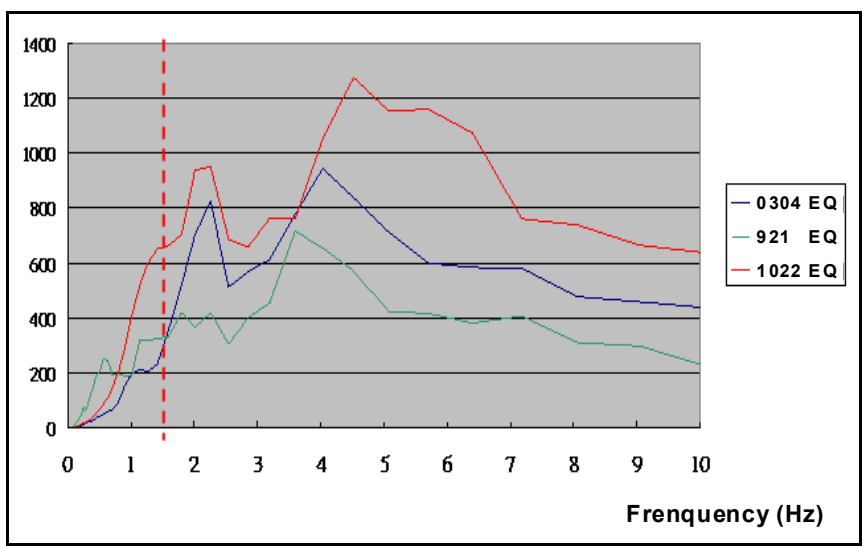

Figure 5: The response spectrum (north-south). 
the traditional retrofit methods of increasing the stiffness of building were not appropriate for this case, or maybe even worse. Buildings which had bigger stiffness would also have bigger natural frequency. For this reason, if we followed the traditional retrofit methods, the stiffness of the temple would be increased and the natural frequency would also get higher.

\section{Retrofit scheme}

Because of the special ground movement characteristics at the temple, we proposed another retrofit scheme by consuming earthquake energy instead of increasing the building's stiffness. We used VEM (Viscous Elastic Material) Damper [5] to achieve this goal. Its own stiffness can reduce the deformation of the buildings and its viscous property can provide damping to consume the energy of the earthquakes. These advantages are appropriate in fighting against earthquakes to raise the safety of buildings. And most important of all, VEM Damper will not increase the building's natural frequency in comparison with the traditional retrofit methods such as adding more columns or walls. This quality quite fits in with the special ground movement characteristics in this case. Table 3 showed the temple's natural frequency after being retrofitted compared to the original temple's natural frequency. The result made clear that the two were almost the same.

Table 3: $\quad$ The temple's natural frequency before and after retrofitting.

\begin{tabular}{|c|c|c|}
\hline Temple's natural frequency & East-west & North-south \\
\hline The temple's natural frequency before retrofitting & $1.56 \mathrm{~Hz}$ & $1.62 \mathrm{~Hz}$ \\
\hline The temple's natural frequency after retrofitting & $1.57 \mathrm{~Hz}$ & $1.62 \mathrm{~Hz}$ \\
\hline
\end{tabular}

The Kelvin Model [6] was used in the computer modeling of VEM Damper. Kelvin Model was composed of a linear elastic element and a damper connected in parallel. After verifying the computer input model of VEM Damper, we added 33 dampers in the computer structural model and ran the dynamic analysis again. The seismic effects would not be infinitely raised when the amount of the damper increased. Thirty-three dampers was the most effective amount after numerous modeling. In addition, the validity of VEM Damper would be influenced in different temperatures. The higher the temperature was, the less effective VEM Damper was. As a result the analyses were conducted in temperatures of $15^{\circ} \mathrm{C}$ and $35^{\circ} \mathrm{C}$. With the results after the computer time-history simulation shown in Table 4, we found out that no matter how the temperature changed, the temple's inter-story drift ratios could all be under $0.5 \%$. 
Table 4: The temple's inter-story drift ratio before and after retrofitting.

The inter-story drift ratio of the front building in east-west direction (\%)

\begin{tabular}{|c|c|c|c|c|c|c|c|}
\hline floor & 1st & 2nd & 3rd & 4th & 5th & 6th & 7th \\
\hline before retrofitted & 0.08 & 0.37 & 0.24 & 0.57 & 0.67 & 0.65 & 0.60 \\
\hline after retrofitted $\left(15^{\circ} \mathrm{C}\right)$ & 0.06 & 0.23 & 0.16 & 0.39 & 0.47 & 0.44 & 0.41 \\
\hline after retrofitted $\left(35^{\circ} \mathrm{C}\right)$ & 0.07 & 0.25 & 0.17 & 0.41 & 0.48 & 0.46 & 0.44 \\
\hline
\end{tabular}

The inter-story drift ratio of the front building in north-south direction (\%)

\begin{tabular}{|c|c|c|c|c|c|c|c|}
\hline Floor & 1st & 2nd & 3rd & 4th & 5th & 6th & 7th \\
\hline before retrofitted & 0.06 & 0.39 & 0.31 & 0.52 & 0.56 & 0.50 & 0.42 \\
\hline after retrofitted $\left(15^{\circ} \mathrm{C}\right)$ & 0.06 & 0.38 & 0.30 & 0.43 & 0.46 & 0.45 & 0.40 \\
\hline after retrofitted $\left(35^{\circ} \mathrm{C}\right)$ & 0.06 & 0.39 & 0.31 & 0.45 & 0.48 & 0.46 & 0.41 \\
\hline
\end{tabular}

The inter-story drift ratio of the back building in east-west direction (\%)

\begin{tabular}{|c|c|c|c|c|}
\hline Floor & 1st & 2nd & $3 \mathrm{rd}$ & \\
\hline before retrofitted & 0.09 & 0.35 & 0.21 & \\
\hline after retrofitted $\left(15^{\circ} \mathrm{C}\right)$ & 0.08 & 0.21 & 0.17 & \\
\hline after retrofitted $\left(35^{\circ} \mathrm{C}\right)$ & 0.08 & 0.23 & 0.18 & \\
\hline \multicolumn{5}{|c|}{ The inter-story drift ratio of the back building in north-south direction (\%) } \\
\hline floor & 1 st & 2nd & $3 \mathrm{rd}$ & \\
\hline before retrofitted & 0.05 & 0.24 & 0.85 & \\
\hline after retrofitted $\left(15^{\circ} \mathrm{C}\right)$ & 0.05 & 0.23 & 0.42 & \\
\hline after retrofitted $\left(35^{\circ} \mathrm{C}\right)$ & 0.05 & 0.24 & 0.45 & \\
\hline
\end{tabular}

In order to compare the traditional retrofit methods with the scheme we proposed, we added the same number of concrete walls instead of VEM Dampers. From Table 5, we found out that the temple's natural frequency increased obviously. According to the ground characteristics of the temple, this result would attract more energy into the building. Table 6 showed the dynamic analysis by using traditional retrofit methods. It was evident that the effects were disappointing. In most of the floors which needed to be improved, the inter-story drift ratios were still higher than $0.5 \%$. 
754 Structural Repairs and Maintenance of Heritage Architecture XII

Table 5: The temple's natural frequency with different retrofit methods.

\begin{tabular}{|c|c|c|}
\hline temple's natural frequency & east-west & north-south \\
\hline temple's natural frequency before retrofitted & $1.56 \mathrm{~Hz}$ & $1.62 \mathrm{~Hz}$ \\
\hline $\begin{array}{c}\text { temple's natural frequency after retrofitted } \\
\text { (VEM Damper) }\end{array}$ & $1.57 \mathrm{~Hz}$ & $1.62 \mathrm{~Hz}$ \\
\hline $\begin{array}{c}\text { temple's natural frequency after retrofitted } \\
\text { (traditional method) }\end{array}$ & $1.91 \mathrm{~Hz}$ & $1.98 \mathrm{~Hz}$ \\
\hline
\end{tabular}

Table 6: The temple's inter-story drift ratio before and after being retrofitted.

the inter-story drift ratio of the front building in east-west direction $(\%)$

\begin{tabular}{|c|c|c|c|c|c|c|c|}
\hline floor & $1 \mathrm{st}$ & 2nd & 3rd & 4th & 5 th & 6 th & 7 th \\
\hline before retrofitted & 0.08 & 0.37 & 0.24 & 0.57 & 0.67 & 0.65 & 0.60 \\
\hline after retrofitted & 0.07 & 0.35 & 0.23 & 0.53 & 0.62 & 0.58 & 0.52 \\
\hline
\end{tabular}

the inter-story drift ratio of the front building in north-south direction (\%)

\begin{tabular}{|c|c|c|c|c|c|c|c|}
\hline floor & 1st & 2nd & 3rd & 4th & 5th & 6th & 7th \\
\hline before retrofitted & 0.06 & 0.39 & 0.31 & 0.52 & 0.56 & 0.50 & 0.42 \\
\hline after retrofitted & 0.06 & 0.38 & 0.31 & 0.48 & 0.53 & 0.48 & 0.40 \\
\hline
\end{tabular}

the inter-story drift ratio of the back building in east-west direction (\%)

\begin{tabular}{|c|c|c|c|}
\hline floor & 1 st & 2nd & 3rd \\
\hline before retrofitted & 0.09 & 0.35 & 0.21 \\
\hline after retrofitted & 0.08 & 0.29 & 0.19 \\
\hline
\end{tabular}

the inter-story drift ratio of the back building in north-south direction (\%)

\begin{tabular}{|c|c|c|c|}
\hline floor & 1 st & 2nd & 3rd \\
\hline before retrofitted & 0.05 & 0.24 & 0.85 \\
\hline after retrofitted & 0.05 & 0.24 & 0.62 \\
\hline
\end{tabular}

\section{Conclusion}

This study discussed that the site characteristics will affect buildings seismic strengthening strategy. An old temple had been strengthened by traditional retrofit methods before but still suffered serious damages from recent earthquakes. In order to find out why traditional methods were useless, we 
studied the strong motion characteristics by using response spectrum analysis. The results indicated that in this case, the traditional retrofit methods made the temple suffer more input energy during earthquakes.

According to previous discussions, we found out that the traditional retrofit schemes were not suitable for all cases. And the reasons usually lied in the geological characteristics. If a building in a certain area would not suffer more earthquake energy while its natural frequency increased, the traditional retrofit strategies were considered most proper. The cost was less and the results were efficient. But if the situation was like this case, the traditional retrofit strategies were not the best choices anymore and the energy consumption strategies were suggested. Therefore, if we could do some researches on the site characteristics of the target buildings before making structural analysis, it would greatly help in choosing the most appropriate retrofit methods.

\section{References}

[1] Tsai Y.C., Huang J.S., Tseng Y.P., Chen W.C. (2000). Detailed Evaluation of the Seismic Capacity of a School Building with Considering Strengthening, National Center for Research on Earthquake Engineering, Taiwan.

[2] Chiou Y.J., Shr J.T., Shiau F.P., Chiou T.J., Ruan J.P., Huang S.J. (2008). Field Test and Analysis for School Building Retrofitted by RC Jacketing System, National Center for Research on Earthquake Engineering, Taiwan.

[3] Chiou Y.J., Liou Y.W., Huang J.C., Shiau F.P., Chiou Y.J., Chiou T.J., Huang S.J. (2008) Field Test and Analysis for School Building Retrofitted by Steel-Framing System, National Center for Research on Earthquake Engineering, Taiwan.

[4] Advanced Civil Engineering Technology (2010). Seismic Retrofit Design of Advanced Civil Engineering Technology Factory Building, Advanced Civil Engineering Technology.

[5] Nippon Steel Corporation (2010). Seismic Technology - VEM Damper. Nippon Steel Corporation, Japan.

[6] Computers and Structures, Inc. (2002). SAP2000 Analysis Reference Manual, Version 8.0. Computers and Structures, Inc., Berkeley. 